\title{
Pemahaman Mahasiswa Tentang Saham Syariah Sebelum dan Sesudah Berdirinya
} Galeri Investasi Syariah BEI (Studi Kasus Pada Mahasiswa FEBI IAIN Bengkulu )

\author{
Desi Isnaini ${ }^{1}$, Cipta Isratul Muslih ${ }^{2}$ \\ Institut Agama Islam Negeri Bengkulu \\ Email:desisnaini@gmail.com ${ }^{1}$, ciptaisratul13@gmail.com ${ }^{2}$
}

\begin{abstract}
The purpose of this study is (1) to find out how students understand of Islamic Economics majors about Islamic stock investments before the establishment of the IDX Islamic Investment Gallery IAIN Bengkulu at the Faculty of Islamic Economics and Business. (2) to find out how students understand of Islamic Economics in the Islamic about stock investment department after the establishment of the Indonesia Stock Exchange Islamic Investment Gallery IAIN Bengkulu at the Faculty of Islamic data in the form is observation, interviews, and documentation. The results of this study is : (1) before enstabilistment GIS many students knows Islamic stocks is still limited to theory because there is no place of practice and educational tools to better understand about Islamic stock investment. (2) after the formation of GIS, students' understanding of sharia shares has increased compared to before the enstabilistment of GIS. Students have used existing support facilities.
\end{abstract}

Keywords : Student Understanding, Sharia Shares, GIS

Abstrak :Tujuan dari penelitian ini adalah (1) untuk mengetahui bagaimana pemahaman mahasiswa jurusan Ekonomi Islam mengenai investasi saham syariah sebelum berdirinya Galeri Investasi Syariah BEI IAIN Bengkulu di Fakultas Ekonomi dan Bisnis Islam. (2) untuk mengetahui bagaimana pemahaman mahasiswa jurusan Ekonomi Islam mengenai investasi saham syariah setelah berdirinya Galeri Investasi Syariah BEI IAIN Bengkulu di Fakultas Ekonomi dan Bisnis Islam. Penelitian yang dilakukan adalah penelitian lapangan (field research) dengan menggunakan metode kualitatif. Data yang digunakan dalam penelitian ini yaitu data primer dan data skunder. Adapun sumber data berupa observasi, wawancara dan dokumentasi. Dari hasil penelitian ini ditemukan bahwa : (1) sebelum berdirinya GIS pemahaman mahasiswa mengenai saham syariah masih sebatas teori dikarenakan belum ada wadah praktik serta sarana edukasi untuk lebih memahami mengenai investasi saham syariah. (2) setelah berdirinya GIS pemahaman mahasiswa mengenai saham syariah lebih meningkat dibandingkan sebelum berdirinya GIS. Mahasiswa sudah memanfaatkan sarana penunjang yang ada.

Kata kunci : Pemahaman Mahasiswa, Saham Syariah, GIS

\section{A. Pendahuluan}

Kehadiran pasar modal berbasis integrasi produk syariah di Indonesia diharapkan dapat membantu bank dan asuransi syariah mengoptimalkan penggunaan sumber dana yang tersedia dengan prinsip syariah sembari menjaga keseimbangan antara likuiditas dan tingkat keuntungan. Selain itu, kehadiran produk syariah di pasar modal Indonesia juga 
membuka peluang berinvestasi bagi masyarakat yang meyakini bahwa produk investasi konvensional mengandung elemen-elemen yang diharamkan syariah. ${ }^{1}$ Pertumbuhan pesat perbankan syariah dan asuransi syariah telah mendorong kebutuhan pasar akan perlunya produk-produk yang mampu mengatasi masalah likuiditas industry keuangan syariah. Kehadiran pasar modal berbasis integrasi produk syariah di Indonesia diharapkan dapat membantu bank dan asuransi syariah mengoptimalkan penggunaan sumber dana yang tersedia dengan prinsip syariah sembari menjaga keseimbangan antara likuiditas dan tingkat keuntungan. Selain itu, kehadiran produk syariah di pasar modal Indonesia juga membuka peluang berinvestasi bagi masyarakat yang meyakini bahwa produk investasi konvensional mengandung elemen-elemen yang diharamkan syariah. ${ }^{2}$

Di era pertumbuhan ekonomi seperti sekarang, peran pasar modal bagi perekonomian nasional memang sangat penting. Terdapat banyak fungsi dan manfaat pasar modal termasuk terkait peran pasar modal dalam perekonomian indonesia. ${ }^{3}$ pasar modal merupakan sarana pembentukan modal dan akumulasi dana yang diarahkan untuk meningkatkan partisipasi masyarakat dalam pengarahan dan berguna penunjang pembiayaan nasioal. Dalam kegiatannya, pemerintah telah memberikan berbagai fasilitas kepada perusahaan yang menawarkan saham/obligasi kepada masyarakat, dengan memberikan kemudahan-kemudahan dan juga memberikan peraturan-peraturan agar kepentingan masyarakat terjamin, sehingga setiap perusahaan yang akan go public diteliti kelayakannya. Pasar Modal di Indonesia sudah dikenal sejak tahun 1912, tetapi karena suasana politik dan ekonomi, kegiatannya terhenti dan baru bisa dikatakan aktif lagi tahun $1976 .{ }^{4}$

UU No.8/1995 tentang Pasar Modal (UUPM), menyebutkan Bahwa Pasar Modal merupakan wadah untuk melakukan transaksi perdagangan berbagai instrumen keuangan jangka panjang, seperti: surat utang (obligasi), ekuitas (saham), reksa dana, instrumen derivatif maupun instrumen lainnya. Trasnsaksi jual beli efek Pasar Modal dilakukan di Bursa Efek, yaitu pihak yang menyelenggarakan dan menyediakan sistem dan atau sarana untuk mempertemukan penawaran jual dan beli efekpihak-pihak lain dengan tujuan memperdagangkan efek diantara mereka. ${ }^{5}$

Perkembangan Pasar Modal di Indonesia kini berkembang sangat pesat, bahkan sudah menjadi tujuan investasi menarik bagi para investor baik dari dalam maupun luar negeri. Pasar modal Indonesia sudah berkembang menjadi salah satu sumber pendanaan jangka panjang bagi dunia usaha. Berbagai program infrastruktur pun turut didorong menggunakan pendanaan dari pasar modal dan pasar modal syariah. ${ }^{6}$

\footnotetext{
${ }^{1}$ Andri Soemitra, Masa Depan Pasar Modal Syariah Di Indonesia (Jakarta: Prenadamedia Group, 2014). h. 1

${ }^{3}$ Mokhammad, "Peran Pasar Modal Dalam Perekonomian Negara Indonesia," HarusPintar.Com, last modified 2018, https://www.haruspintar.com/peran-pasar-modal-dalam-perekonomian/.

${ }^{4}$ Kamaruddin Ahmad, Dasar-Dasar Manajemen Investasi Dan Portopolio (Jakarta: PT Rineka Cipta, 2004). h. 17

${ }^{5}$ Ticmi, Pengetahuan Tentang Efek Yang Diperdagangkan Di Pasar Modal (Jakarta Selatan: Ticmi, 2016). h. 3

${ }^{6}$ Nur Aini, “OJK: Pasar Modal Indonesia Berkembang Sangat Pesat,” Republika.Co.Id, last modified 2017, https://www.republika.co.id/berita/ekonomi/keuangan/17/08/13/oulvh0382-ojk-pasar-modal-indonesiaberkembang-sangat-pesat.
} 
Pasar modal syariah adalah pasar modal yang sesuai dengan syariah Islam atau dengan kata lain instrument yang digunakan berdasarkan pada prinsip syariah dan mekanisme yang digunakan juga tidak bertentangan dengan prinsip syariah. Perkembangan investasi syariah di Indonesia semakin menunjukkan peningkatan. Hal ini terlihat dari beberapa angka indikator pasar modal yang menunjukkan pertumbuhan. Tercatat jumlah total investor syariah pada bulan April 2018 meningkat sekitar 28\% dari sebelumnya pada tahun 2017 tercatat 23.207 investor menjadi 29.670 investor pada tahun 2018. Tren pertumbuhan serupa terlihat juga pada sisi tingkat keaktifan investor syariah yang bertumbuh secara signifikan Hingga 43\%. Sementara itu, dilihat dari segi indikator transaksi, Bursa Efek Indonesia mencatat saat ini nilai transaksi investor syariah telah mencapai Rp 596 Milyar dengan volume saham yang telah di transaksikan hingga bulan April 2018 yaitu sebanyak 2 Milyar saham dan hingga frekuensi transaksi perdagangan Saham terjadi sebanyak 197 ribu kali. Dari total 34 provinsi di Indonesia, diketahui 10 besar provinsi memiliki jumlah investor saham syariah terbanyak dimana pada peringkat Pertama ditempati oleh Jawa Timur dengan total 4.374 investor, disusul oleh Jawa Barat dengan total 3.784 investor. Kemudian tercatat DKI Jakarta, Jawa Tengah, D.I Yogyakarta, Sumatera Barat, Banten, Bengkulu, Kalimantan Barat, dan Sulawesi Barat menjadi bagian dari 10 besar tersebut.

Pencapaian ini bukanlah merupakan hasil instan, melainkan hasil kerja keras tidak hanya dari Pemerintah, akan tetapi juga berbagai perusahaan Sekuritas, dan lembaga/asosiasi seperti Otoritas Jasa keuangan, Masyarakat Ekonomi Syariah, Ikatan Ahli Ekonomi Islam, Organisasi mahasiswa Fossei dan Galeri Investasi serta Galeri Investasi Syariah yang dimana secara konsisten terus berupaya meningkatkan literasi masyarakat terhadap ekonomi dan keuangan syariah, termasuk Pasar Modal Syariah.

Galeri investasi Bursa Efek Indonesia (BEI) adalah sarana untuk memperkenalkan pasar modal Sejak dini kepada dunia akademisi. Galeri investasi BEI Berkonsep 3 In 1 Yang Merupakan kerjasama antara BEI, perguruan tinggi dan perusahaan sekuritas diharapkan tidak hanya memperkenalkan pasar modal dari sisi teori saja akan tetapi juga prakteknya. Kedepannya melalui galeri investasi BEI Yang Menyediakan real time information untuk belajar menganalisa aktivitas perdagangan saham, Diharapkan dapat menjadi jembatan menuju penguasaan ilmu pengetahuan beserta prakteknya di pasar modal. $^{7}$

Galeri Investasi BEI menyediakan semua publikasi dan bahan cetakan mengenai pasar modal yang diterbitkan oleh bursa efek indonesia termasuk peraturan dan undangundang pasar modal. Informasi dan data yang ada di Galeri Investasi BEI dapat digunakan oleh civitas akademika untuk tujuan akademik, bukan untuk tujuan komersial dalam hal transaksi jual dan beli saham.

Dengan adanya Galeri Investasi BEI diharapkan dapat saling memberikan manfaat bagi semua pihak sehingga penyebaran informasi pasar modal tepat sasaran serta dapat memberikan manfaat yang optimal bagi mahasiswa, praktisi ekonomi, investor, pengamat pasar modal maupun masyarakat umum di daerah dan sekitarnya baik untuk kepentingan sosialisasi dan pendidikan/edukasi pasar modal maupun untuk kepentingan ekonomis atau alternatif investasi. Manfaat bagi para pihak, bagi bursa efek Indonesia, sebagai sarana sosialisasi \& edukasi di kalangan akademis agar dapat terlaksana dengan baik,

\footnotetext{
${ }^{7}$ Mokhammad, "Peran Pasar Modal Dalam Perekonomian Negara Indonesia."
} 
sehingga diharapkan civitas akademika tidak hanya mengenal pasar modal dari sisi teori saja akan tetapi dapat langsung melakukan prakteknya. Bagi perguruan tinggi, ada aliansi strategis dengan para pelaku pasar modal (BEI, AB, Data Vendor) meningkatkan brand name dan nilai jual perguruan tinggi. bagi perusahaan efek anggota bursa, sebagai langkah media promosi dikalangan mahasiswa/akademisi dan sebagai media recruitment sumber daya manusia pasar modal yang handal. Bagi data vendor, sebagai langkah media promosi produk data dikalangan akademisi, tidak mengeluarkan investasi hardware untuk pojok BEI \& lab pasar modal dan sebagai media recruitment sumber daya manusia pasar modal yang handal.

Saat ini galeri investasi banyak berdiri di seluruh Indonesia. Dengan total keseluruhan 408 galeri investasi.Bursa efek Indonesia kantor perwakilan provinsiBengkulu memiliki total 6 galeri investasi. 4 galeri investasi umum dan 2 galeri investasi syariah masing- masing galeri berada di lingkungan kampus. Galeri investasi syariah pertama di Provinsi Bengkulu adalah Galeri Investasi Syariah BEI di IAIN Bengkulu yang diresmikan pada tanggal 21 September 2016 bekerjasama dengan Perusahaan PT FAC Sekuritas Indonesia sebagai sarana sosialisasi \& edukasi di kalangan akademis agar dapat terlaksana dengan baik. Denganberdirinya Galeri Investasi Syariah BEI di IAIN Bengkulu, civitas akademika tidak hanya mengenal pasar modal dari sisi teori saja akan tetapi dapat langsung melakukan prakteknya. Berdasarkan data per tanggal 16 Oktober 2018 tercatat investor pada GIS BEI IAIN Bengkulu berjumlah 1047 investor dengan jumlah nilai transaksi Rp. 11.249.536.500., dengan keadaan perkembangan yang demikian berbanding terbalik dengan pemahaman mahasiswa. Penelitian ini membahas bagaimana pemahaman mahasiswa Jurusan Ekonomi Islam Fakultas Ekonomi dan Bisnis Islam tentang saham syariah sebelum dan sesudah berdirinya Galeri Investasi Syariah BEI IAIN Bengkulu di Fakultas Ekonomi dan Bisnis Islam.

\section{B. Metode}

Penelitian ini digolongkan kedalam penelitian field research. Pendekatan yang digunakan dalam penelitian ini adalah pendekatan deskriptif kualitatif. Teknik penentuan informan penelitian menggunakan teknik purposive sampling, yakni mahasiswa jurusan Ekonomi Islam FEBI IAIN Bengkulu.

Sumber data pada penelitian ini berasal dari sumber data primer dan sekunder, Dengan teknik pengumpulan data berupa observasi, dokumentasi, wawancara. Teknik analisis data menggunakan teknik analisis dari Miles dan Huberman, yang diawali dengan pengumpulan data kemudian reduksi data, display data dan terakhir menarik kesimpulan. Untuk mengetahui dan membandingkan pemahaman mahasiswa tentang saham syari'ah sebelum dan sesudah adanya Galeri Investasi Syari'ah IAIN Bengkulu.

\section{Hasil dan Pembahasan}

\section{Pemahaman Mahasiswa Tentang Saham Syariah Sebelum Berdirnya Galeri Investasi Syariah BEI IAIN Bengkulu}

Berdasarkan hasil penelitian yang penulis lakukan baik dengan wawancara langsung kepada mahasiswa maupun dengan cara observasi yang penulis lakukan untuk mengetahui pemahaman mahasiswa sebelum berdirinya Galeri Investasi Syariah BEI IAIN Bengkulu di Fakultas Ekonomi dan Bisnis Islam (Studi Pada Mahasiswa Jurusan Ekonomi Islam) dengan uraian sebagai berikut. 
Untuk mengetahui pemahaman mahasiswa tentang saham syariah sebelum berdirinya Galeri Investasi Syariah BEI IAIN Bengkulupenulis mengambil sampel pada alumni mahasiswa Jurusan Ekonomi Islam5 orang yang telah mengambil matakuliah manajemen investasi sebelum Galeri Investasi Syariah IAIN Bengkulu berdiri. Dari hasil wawancara yang penulis lakukan dengan alumni mahasiswa Jurusan Ekonomi Islam dapat dilihat bagaimana penjelasan dan pemahaman mahasiswa tentang saham syariah sebelum berdirinya galeri investasi syariah BEI IAIN Bengkulu. Beberapa pernyataan mengenai konsep saham syariah antara lain sebagai berikut: Ade Frankoe alumni angkatan 2013 menyatakan:

"Saya sebagai alumni kalauditanya mengenai pasar modal, saham, saham syariah, istilah-istilah dalam pasar modal saya tidak terlalu paham mengenai itu. Saya tahu sedikit pengertian saham, saham adalah bukti penyertaan modal.Saya hanya tau teorinya saat itu sekarang sudah lupa.waktu dibangku kuliah memang sudah belajar manajemen investasi. Tapi saat itu laboratorium Ekonomi IslamGaleri Investasi Syariah BEI IAIN Bengkulu belum berdiri. Jadi belum tau praktiknya". ${ }^{8}$

Sama halnya seperti yang dijelaskan oleh Muhammad Ramadhan selaku (alumni Perbankan Syariah) mengenai investasi saham syariah, "saya tidak paham, pernah tahu, hanyamendengar saja karena dulu pernah belajar matakuliah manajemen investasi pasar modal, saya hanya tahu saham itu surat hutang".

Penulis juga melakukan wawancara dengan Yeni Sartika (alumni Perbankan Syariah) yang sudah bekerja di perusahaan sekuritas. Informan menyatakan "sama seperti yang teman-teman alumni yang lain, kalau ditanya apa itu saham syariah dulu masih bingung, memang dulu sudah belajar manajemen investasi pasar modal tapi belum praktik bagaimana, seperti apa itu transaksi saham, cara jual beli dan lain-lain karena memang belum ada tempat praktiknya, kebetulan saya pernah magang di Bursa Efek Indonesia KPW Bengkulu disana saya mulai memahami kemudian berlanjut bekerja di perusahaan sekuritas jadi bisa lebih paham"Saham syariah adalah sertifikat yang menunjukakan bukti kepemilikan suatu perusahaan yang diterbitkan oleh emiten yang kegiatan usaha maupun cara pengelolaannya tidak bertentangan dengan prinsip syariah."10

Lanjut menurut Lisa Maryana (alumni Perbankan syariah) "Saham syariah adalah sertifikat yang menunjukakan bukti kepemilikan suatu perusahaan, hanya itu yang sayang ingat" ${ }^{11}$

Dapat ditarik kesimpulan bahwa pemahaman mahasiswa tentang saham syariah sebelum berdirinya Galeri Investasi Syariah BEI IAIN Bengkulu di Fakultas Ekonomi dan Bisnis Islam tergolong pada Pemahaman intruksional (Intructional Understanding) tingakatan ini dapat dikatakan bahwa mahasiswa baru berada ditahap tahu atau hapal tetapi dia belum tahu atau tidak tahu mengapa hal itu bisa dan dapat terjadi. Dan dengan berdasarkan indikator pemahaman menurut Kenneth

\footnotetext{
${ }^{8}$ Ade Frankoe, Alumni Prodi Perbankan Syariah Angkatan 2013, Wawancara tanggal 14 Januari 2018

${ }^{9}$ Muhammad Ramadhan, Alumni Prodi Perbankan Syari'ah 2013, Wawancara tanggal 14 Januari 2018

${ }^{10}$ Yeni Sartika, Alumni Prodi Perbankan Syariah Angkatan 2013, Wawancara tanggal 8 Maret 2019

${ }^{11}$ Lisa Maryana, Alumni Prodi Perbankan Syariah Angkatan 2013, Wawancara tanggal 11 Maret 2019
} 
D. Mooredalam buku Mahesa Kapadia, pemahaman mahasiswa tentang saham syariah belum memenuhi Indikator yang menunjukkan pemahaman konsep yaitu menyatakan ulang sebuah konsep, mengklasifikasi objek-objek menurut sifat-sifat tertentu (sesuai dengan konsepnya), memberi contoh dan non-contoh dari konsep, menyajikan konsep dalam berbagai bentuk representasi matematis, mengembangkan syarat perlu atau syarat cukup suatu konsep, menggunakan, memanfaatkan, dan memilih prosedur atau operasi tertentu dan mengaplikasikan konsep atau algoritma pemecahan masalah. ${ }^{12}$

Selanjutnya pernyataan mengenai peran dan urgensi galeri Investasi Syariah BEI IAIN Bengkulu dalam mensosialisasikan saham syariah. Menurut Yeni Sartika (alumni Perbankan Syariah) angkatan 2013 sebagai berikut:

"Dengan berdirinya Galeri Investasi Syariah BEI IAIN Bengkulu di Fakultas Ekonomi dan Bisnis Islam ini sangat membantu sekali bagi mahasiswa khususnya, tidak terkecuali juga untuk umum mengingat tujuan pendirian GISadalah sebagai sarana untuk memperkenalkan pasar modal sejak dini kepada dunia akademisi. Galeri investasi BEI Berkonsep 3 In 1 Yang Merupakan kerjasamaantara BEI, Perguruan tinggi dan Perusahaan Sekuritas diharapkan tidak hanya memperkenalkan pasar modal dari sisi teori saja akan tetapi juga prakteknya yang sinergi dengan teori dari mata kuliah dari manajemen investasi pasar modal. Jadi, mahasiswa lebih mudah memahami praktikdari teori yang didapatkan ketika dikelas". ${ }^{13}$

Sama halnya dengan Lisa Maryana (alumni Perbankan Syariah) menjelaskan sumbangsih, peran dan urgensi GIS dalam mensosialisasikan saham syariah "Dilihat sekarang dengan adanya GIS mahasiswa lebih mudah paham, ketika sebelum adanya GIS memang agak susah memahami materi karena butuh praktek langsung, waktu itu belum ada tempat praktik, keberadaan GIS membantu, berperan dalam mensosialisasikan saham"14

Penulis juga melakukan wawancara dengan 2 orang alumni Perbankan lainnya yaitu Ade Frankoe dan Muhammad Ramadhan. Mereka menjelaskan bahwa keberadaan galeri sangat membantu mahasiswa, melihat perkembangan galeri juga bagus. $^{15}$

Dari hasil penelitian penulis di lapangan serta hasil wawancara yang penulis lakukan dengan mahasiswa, ada berbagai faktor yang mempengaruhi pemahaman mahasiswa Jurusan Ekonomi Islam sebelum berdirinya Galeri Investasi Syariah terhadap saham syariah, faktor-faktor yaitu pertama, Faktor Informasi. Informasi akan memberikan pengaruh kepada seseorang atau masyarakat itu sendiri mengenai suatu hal dan bisa mempengaruhi pemahaman mahasiswa. Dari data yang ada, hasil penelitian yang telah peneliti lakukan dilapangan dan hasil wawancara, dimana mereka beranggapan pemahaman mereka mengenai investasi saham syariah baru sekedar teori saja dikarenakan belum ada wadah untuk

${ }^{12}$ Mahesa Kapadia, Daya ingat: Bagimana mendapatkan yang terbaik, (Jakarta: Pustaka Populer Obot, 2001), h. 12

${ }^{13}$ Yeni Sartika, Alumni Prodi Perbankan Syariah Angkatan 2013, Wawancara tanggal 8 Maret 2019

${ }^{14}$ Lisa Maryana, Alumni Prodi Perbankan Syariah Angkatan 2013, Wawancara tanggal 11 Maret 2019

${ }^{15}$ Ade Frankoe, Muhammad Ramadhan, Alumni Prodi Perbankan Syariah Angkatan 2013, Wawancara tanggal 8 Maret 2019 
mendapatkan informasi mengenai mekanisme investasi saham syariah. Kurangnya informasi tersebut akan mempengaruhi pemahaman mahasiswa tentang saham syariah sehingga pemahaman mahasiswa sebelum berdirinya galeri investasi syariah masih kurang. Kedua, Faktor Intelegensia. Intelegensia diartikan sebagai suatu kemampuan untukbelajar dan berfikir abstrak guna menyesuaikan diri secara mental dalam situasi baru. Intelegensia merupakan salah satu faktor yang memepengaruhi hasil dari proses belajar. Intelegensia bagi seseorang merupakan salah satu modal untuk berfikir dan mengolah berbagai informasi secara terarah sehingga ia mampu menguasai lingkungan. Karena pada dasarnya, faktor intelegensia sangat mempengaruhi seseorang untuk mencari informasi dari dalam pribadi guna meningkatkan pengetahuan dan pemahaman. Ketiga, Sosial budaya dan ekonomi. Sosial budaya mempunyai pengaruh pada pemahaman seseorangan. Seseorang memperoleh suatu kebudayaan dalam berhubungan dengan orang lain, karena hubungan ini seseorang mengalami suatu proses belajar dan memperoleh suatu pemahaman. Suatu ekonomi seseorang juga akan menenentukan tersedianya suatu fasilitas yang diperlukan untuk kegiatan tertentu, sehingga status sosial ekonomi ini akan mempengaruhi pemahaman seseorang.

2. Pemahaman Mahasiswa Tentang Saham Syariah Setelah Berdirinya Galeri Investasi Syariah BEI IAIN Bengkulu

Pemahaman mahasiswa tentang saham syariah sesudah berdirinya Galeri Investasi Syariah BEI IAIN Bengkulu penulis mengambil sampel pada mahasiswa Jurusan Ekonomi Islam yang telah mengambil matakuliah manajemen investasi sebelum Galeri Investasi Syariah BEI IAIN Bengkulu berdiri. Penulis mengambil sampel pada mahasiswa sebanyak 15 adalah mahasiswa Mahasiswa Jurusan Ekonomi Islam 8 orang dari Prodi Ekonomi Syariah dan 7 orang dari Perbankan Syariah semester 7 dengan kreteria mendapatkan nilai A pada matakuliah manajemen investasi pasar modal yang sinergi dengan keberadaan Galeri Investasi Syariah BEI IAIN Bengkulu di Fakultas Ekonomi dan Bisnis Islam. Dari hasil penjelasan yang penulis lakukan dengan mahasiswa dapat dilihat bagaimana penjelasan dan pemahaman mahasiswa tentang saham syariah sesudah beridirinya galeri investasi syariah BEI IAIN Bengkulu. Pertanyaan yang peneliti ajukan kepada mahasiswa mengenai investasi saham syariah. Menurut Andi Mustahrinal (mahasiswa Prodi Ekonomi Syariah) 22 tahun saham syariah adalah sertifikat yang menunjukakan bukti kepemilikan suatu perusahaan yang diterbitkan oleh emiten yang kegiatan usaha maupun cara pengelolaannya tidak bertentangan dengan prinsip syariah. dalam prinsip, penyertaan modal dilakukan pada perusahaan-perusahaan yang tidak melanggar prinsip-prinsip syariah, seperti bidang perjudian, riba, memproduksi barang yang diharamkan seperti minuman berakohol. Beberapa saham syariah yang terdaftar di JakartaIslamic Index (JII) yaitu ADRO, ANTM, INDF. ${ }^{16}$

Hal ini diperkuat informan dengan membuktikan dengan meperlihatkan akun saham yang dimilikinya dan dengan hasil wawancara dari 15 informan yang dilakukan wawancara, 11 orang lainnya mampu menyatakan ulang pengertian saham syariah,menyebutkan karakteristik saham syariah serta memberikan panjelasan

\footnotetext{
${ }^{16}$ Andi Mustahrinal, Mahasiswa Perbankan Syariah Angkatan 2015, Wawancara tanggal 16 Januari 2018
} 
atau memberi uraian yang lebih rinci tentang saham syariah dengan mampu menyebutkan beberapa saham syariah itu dengan menggunakan kata-katanya sendiri.Dalam wawancara 4 orang selanjutnya, disimpulkan bahwa informan tidak mampu menjelaskan apa yang dimaksud dengan saham syariahdengan benar. Dalam wawancara yang dilakukan oleh peneliti kepada saudari Dita Syafitri Awaliah mahasiswa prodi Perbankan Syariah (22 tahun), saudari dita menjelaskan bahwa "kalau ditanyakan pengertian sekarang saya tidak tahu, saya lupa karena belajar tentang investasi itu semester lalu, saya sudah mengambil matakuliah itu manajemen investasi pasar modal kemudian saya membuka akun, tetapi tidak saya akses lagi karena saya lupa pin dan password akun saya itu". ${ }^{17}$

Menurut Desiyani Rachmadhani Pratiwi mahasiswa prodi Perbankan Syariah (22 tahun) mengungkapkan bahwa "saya tidak tahu apa pasar modal apalagi saham syariah". ${ }^{18}$ Menurut saudari Umi Wahiddatur Rohmatin Fitriamahasiswa prodi Ekonomi Syariah (22 tahun) menjelaskan bahwa "saya tidak paham apa itu saham syariah".

Menurut saudari Puspita Septi Wiani mahasiswa prodi Perbankan Syariah (22 tahun) bependapat, akan hal sama seperti pada wawancara sebelumnya bahwa tidak tahu apa pengertian saham syariah dikarenakan lupa akan materi tentang itu.

Menurut Andi Mustahrinal selaku mahasiswa Prodi Ekonomi Syariah mengungkapkan sebagai berikut :

"Dengan berdirinya Galeri Investasi Syariah BEI IAIN Bengkulu di Fakultas Ekononomi dan Bisnis Islam sangat membantu dalam meningkatkan pengetahuan mahasiswa dalam dunia pasar modal khususnya investasi saham syariah, dengan adaya galeri investasi syaraih di Fakultas Ekonomi dan Bisnis Islam mahasiswa bisa mendapatkan dengan mudah informasi mengenai saham syari'ah. ${ }^{19}$

Fitri Handayani (mahasiswa prodi Ekonomi Syariah) berpendapat bahwa "Dengan adanya Galeri Investasi Syariah di Fakultas Ekonomi dan Bisnis Islam jelas sangat membantu mahasiswa". ${ }^{20}$ Menurut Rudi Anto Saputra, (mahasiswa prodi Ekonomi Syariah) berpendapat bahwa "Dengan adanya Galeri Investasi di Fakultas Ekonomi dan Bisnis Islam tentu sangat membantu mahasiswa khususnya dalam pemahaman mahasiswa bisa bertanya langsung ke pihak GIS". ${ }^{21}$ Selanjutnya, menurut Nanda Alfian (mahasiswa prodi Ekonomi Syariah) Dengan adanya Galeri Investasi Syariahdi Fakultas Ekonomi dan Bisnis Islam, jelas membantu mahasiswa". ${ }^{22}$ Menurut Romi Maryadi(mahasiswa prodi Ekonomi Syariah) Dengan adanya Galeri Investasi Syariah di Fakultas Ekonomi dan Bisnis Islam mahasiswa

\footnotetext{
17 Dita Syafitri Awaliah, mahasiswa Perbankan Syariah Angkatan 2015, Wawancara tanggal 18 Januari 2018

${ }^{18}$ Desiyani Rachmadani Pratiwi, mahasiswa prodi Perbankan Syariah Angkatan 2015, Wawancara tanggal 18 Januari 2018

19 Andi Mustahrinal, Mahasiswa Prodi Ekonomi Syariah Angkatan 2015, Wawancara tanggal 16 Januari 2018

${ }^{20}$ Fitri Handayani, Mahasiswa Prodi Perbankan Syariah Angkatan 2015, Wawancara tanggal 16 Januari 2018

${ }^{21}$ Rudi Anto Saputra , Mahasiswa Prodi Ekonomi Syariah Angkatan 2015, Wawancara tanggal 17 Januari 2018

${ }^{22}$ Nanda Alfian, Mahasiswa Prodi Ekonomi Syariah Angkatan 2015, Wawancara tanggal 17 Januari 2018
} 
lebih mudah untuk menggali informasi dan membantu dalam pemahaman mengenai investasi saham syariah". ${ }^{23}$

Menurut Murlia Dwi Hastami (mahasiswa prodi Ekonomi Syariah),"setelah adanya Galeri Investasi Syariah di Fakultas Ekonomi dan Bisnis Islamsangat membantu mahasiswa dalam pemahaman, pihak GIS sering mengadakan kegiatan- kegiatan yang berkaitan dengan pasar modal". 24

Lanjut Nensi Permata Sari, (mahasiswa prodi Ekonomi Syariah) "setelah adanya Galeri Investasi Syariah di Fakultas Ekonomi dan Bisnis Islam mahasiswa lebih mudah memahami dengan praktik langsung bagaimana mekanisme bertransaksi jual beli saham". ${ }^{25} \mathrm{Nur}$ Ainun, (mahasiswa prodi Perbankan Syariah),"setelah adanya Galeri Investasi Syariah di Fakultas Ekonomi dan Bisnis Islam sangat membantu mahasiswa dan berperan dalam meningkatkan pemahaman dengan adanya wadah praktik mempermudah mahasiswa dalam membantu pemahaman". 26

Sedangkan Miftahul falah (mahasiswa prodi Ekonomi Syariah), "setelah adanya Galeri Investasi Syariah di Fakultas Ekonomi dan Bisnis Islam mahasiswa lebih mudah memahami praktik dari mata kuliah manajemen investasi pasar modal dengan terjun langsung mempraktikan mekanisme bertransaksi jual beli saham syariah". ${ }^{27}$ Irfan Afarizi (mahasiswa prodi Ekonomi Syariah), "setelah Galeri Investasi Syariah berdiri di Fakultas Ekonomi dan Bisnis Islam mahasiswa lebih mudah memahami praktik dari teori yang dipelajari di kelas. ${ }^{28}$

Mengenai peran dan urgensi Galeri Investasi Syariah BEI IAIN Bengkulu dalam mensosialisasikan saham syariah khususnya kepada mahasiswa Jurusan Ekonomi Islam, Menurut Rudi Anto Saputra selaku mahasiswa Prodi Ekonomi Syariah mengungkapkan bahwa Galeri investasi Bursa Efek Indonesia BEI Adalah sarana untuk memperkenalkan Pasar Modal sejak dini kepada dunia akademisi. Galeri investasi BEI Berkonsep 3 In 1 Yang Merupakan kerjasama antara BEI, perguruan tinggi dan perusahaan sekuritas. Peran Galeri Investasi tidak hanya memperkenalkan pasar Modal dari sisi teori saja akan tetapi juga prakteknya. Menurut Rudi Anto Saputra peran Galeri Investasi Syariah BEI IAIN Bengkulu di Fakultas ekonomi dan bisnis Islam sangat membantu dalam pemahaman mahasiwa sesuai dengan tujuan pendirian galeri investasi didunia akademisi. Mahasiswa lebih mudah memahami karena mempraktikan secara langsung mekanisme jual beli saham syariah dengan menggunakan aplikasi Online trading dari Perusahaan sekuritas PT FAC Sekuritas Indonesia yang bekerja sama dengan Galeri Investasi Syariah BEI IAIN Bengkulu.Ditambahkannya

\footnotetext{
${ }^{23}$ Romi Maryadi Mahasiswa Prodi Ekonomi Syariah Angkatan 2015, Wawancara tanggal 17 Januari 2018

${ }^{24}$ Murlia Dwi, Mahasiswa Prodi Ekonomi Syariah Angkatan 2015, Wawancara tanggal 17 Januari 2018

${ }^{25}$ Nensi Permata sari, Mahasiswa Prodi Ekonomi Prodi Syariah Angkatan 2015, Wawancara tanggal 20 Januari 2018

${ }^{26}$ Nur Ainun Mahasiswa Prodi Ekonomi Syariah Angkatan 2015, Wawancara tanggal 20 Januari 2018

27 Miftakhul falah Mahasiswa Prodi Ekonomi Syariah Angkatan 2015, Wawancara tanggal 20 Januari 2018

${ }^{28}$ Irfan Alfarizi, Mahasiswa Prodi Ekonomi Syariah Angkatan 2015, Wawancara tanggal 20 Januari 2018
} 
bahwa banyak kegiatan yang dilakukan pihak pengurus Galeri Investastasi syariah BEI IAIN Bengkulu yang tergabung antara dosen-dosen, karyawan PT FAC Sekuritas bersama dengan Bursa Efek Indonesia serta mahasiswa kelompok studi pasar modal sebagai upaya mensosialisasikan saham syariah seperti sekolah pasar modal (SPM), workshop pasar modal serta event-event yang berkaitan dengan pasarmodal. ${ }^{29}$

Berdasarkan hasil penelitian yang dilakukan penulis di lapangan, diperoleh data memberikan berbagai macam informasi. Data dari hasil wawancara tersebut dapat disimpulkan bahwa sebelum berdirinya galeri investasi syariah pemahaman mahasiswa tentang saham syariah tergolong pada kategori pemahaman intruksional (intructional understanding). Setelah berdirinya galeri investasi syariah BEI IAIN Bengkulu pemahaman mahasiswa tentang saham syariah tergolong pada tingkatan paham Pemahaman rasional (Rational Understanding) menurut Skemp yakni masyarakat tidak hanya sekedar tahu dan hapal tentang suatu hal, tetapi ia juga tahu bagaimana dan mengapa hal itu dapat terjadi. Pada dasarnya tingkat pahamdapat diartikan sebagai tingkat pengetahuan yang sudah dapat digunakan untuk menjelaskan apa yang diketahui dengan benar. ${ }^{30}$ Dan berdasarkan indikator pemahaman dari Indikator pemahaman menurut Kenneth D. MooreMoore dalam buku Mahesa Kapadia Indikator yang menunjukkan pemahaman konsep antara lain adalah menyatakan ulang sebuah konsep, mengklasifikasi objek-objek menurut sifat-sifat tertentu (sesuai dengan konsepnya), memberi contoh dan non-contoh dari konsep, menyajikan konsep dalam berbagai bentuk representasi matematis, mengembangkan syarat perlu atau syarat cukup suatu konsep, menggunakan, memanfaatkan, dan memilih prosedur atau operasi tertentu dan mengaplikasikan konsep atau algoritma pemecahan masalah.

Hasil penelitian penulis di lapangan serta hasil wawancara yang penulis lakukan dengan informan, hasil wawancara yang dilakukan pada 15 orang narasumber selanjutnya. Disimpulkan bahwa keseluruhan informan menyatakan bahwa Galeri Investasi Syariah BEI IAIN Bengkulu berperan baik dalam dalam membantu pemahaman mahasiswa dengan upaya-upaya sosialisasi yang dilakukan. Mahasiswa lebih memahami praktik dari teori pembelajaran matakuliah manajemen investasi pasar modal yang sinergi keberadaannya dengan Galeri Investasi Syariah BEI IAIN Bengkulu sebagai sarana untuk memperkenalkan Pasar Modal sejak dini kepada dunia akademisi.

\section{Simpulan}

Hasil penelitian disimpulkan bahwa Pemahaman mahasiswa mengenai saham syariah sebelum berdirinya Galeri Investasi syariah BEI IAIN Bengkulu tergolong pada pemahaman instruksional (Intructional Understanding) dan berdasarkan indikator pemahaman dari Kennet D. Moore belum memenuhi syarat. Dari ke 4 informan alumni hanya mampu menyatakan ulang teori saham syariah, tidak begitu paham mekanisme transaksi jual beli saham. Adapun kendala yang mengahambat pemahaman mahasiswa ada

\footnotetext{
${ }^{29}$ Rudi Anto Saputral, Mahasiswa Perbankan Syariah Angkatan 2015, Wawancara tanggal 17 Januari 2018

${ }^{30}$ Mahesa Kapadia, Daya Ingat: Bagimana Mendapatkan Yang Terbaik (Jakarta: Pustaka Populer Obot, 2001). h. 10
} 
beberapa faktor , diantaranya ; Faktor internal, yaitu intelegensia, dan faktor eksternal, informasi, serta sosial budaya dan ekonomi. Selanjutnya Pemahaman mahasiswa tentang saham syariah setelah berdirinya Galeri Investasi syariah BEI IAIN Bengkulu disimpulkan tergolong pada pemahaman rasional (Rational Instruction) dan berdasarkan indikator pemahaman dari Kennet D. Moore telah memenuhi syarat. Dari 15 Informan, 11 diantaranya mampu menyatakan ulang, menyebutkan kreteria, mengklarifkasikan objek, memberikan contoh dan membuktikan bahwa sudah mengaplikasikan teorinya secara langsung sehingga peran Galeri Investasi Syariah BEI IAIN Bengkulu sebagai wadah edukasi terealisasi.

\section{Daftar Pustaka}

Ahmad, Kamaruddin. Dasar-Dasar Manajemen Investasi Dan Portopolio. Jakarta: PT Rineka Cipta, 2004.

Aini, Nur. "OJK: Pasar Modal Indonesia Berkembang Sangat Pesat.” Republika.Co.Id. Last modified

https://www.republika.co.id/berita/ekonomi/keuangan/17/08/13/oulvh0382-ojk-pasarmodal-indonesia-berkembang-sangat-pesat.

Alfian, Nanda. Mahasiswa Prodi Ekonomi Syariah Angkatan 2015. Wawancara tanggal 17 Januari 2018.

Ainun, Nur. Mahasiswa Prodi Ekonomi Syariah Angkatan 2015. Wawancara tanggal 20 Januari 2018.

Alfarizi, Irfan. Mahasiswa Prodi Ekonomi Syariah Angkatan 2015. Wawancara tanggal 20 Januari 2018.

Awaliah, Dita Syafitri. Mahasiswa Perbankan Syariah Angkatan 2015. Wawancara tanggal 18 Januari 2018.

Dwi, Murlia. Mahasiswa Prodi Ekonomi Syariah Angkatan 2015. Wawancara tanggal 17 Januari 2018.

Falah, Miftakhul. Mahasiswa Prodi Ekonomi Syariah Angkatan 2015. Wawancara tanggal 20 Januari 2018.

Kapadia, Mahesa. Daya Ingat: Bagimana Mendapatkan Yang Terbaik. Jakarta: Pustaka Populer Obot, 2001.

Maryadi, Romi. Mahasiswa Prodi Ekonomi Syariah Angkatan 2015. Wawancara tanggal 17 Januari 2018.

Maryana, Lisa. Alumni Prodi Perbankan Syariah Angkatan 2013, Wawancara tanggal 11 Maret 2019.

Mustahrinal, Andi. Mahasiswa Perbankan Syariah Angkatan 2015. Wawancara tanggal 16 Januari 2018.

Mokhammad. "Peran Pasar Modal Dalam Perekonomian Negara Indonesia." HarusPintar.Com. Last modified 2018. https://www.haruspintar.com/peran-pasarmodal-dalam-perekonomian/. 
Maryadi, Romi. Mahasiswa Prodi Ekonomi Syariah Angkatan 2015. Wawancara tanggal 17 Januari 2018.

Maryana, Lisa. Alumni Prodi Perbankan Syariah Angkatan 2013, Wawancara tanggal 11 Maret 2019.

Mustahrinal, Andi. Mahasiswa Perbankan Syariah Angkatan 2015. Wawancara tanggal 16 Januari 2018.

Pratiwi, Desiyani Rachmadani. Mahasiswa prodi Perbankan Syariah Angkatan 2015. Wawancara tanggal 18 Januari 2018.

Saputral, Rudi Anto. Mahasiswa Perbankan Syariah Angkatan 2015. Wawancara tanggal 17 Januari 2018.

Sari, Nensi Permata. Mahasiswa Prodi Ekonomi Prodi Syariah Angkatan 2015. Wawancara tanggal 20 Januari 2018.

Sartika, Yeni. Alumni Prodi Perbankan Syariah Angkatan 2013. Wawancara tanggal 8 Maret 2019.

Soemitra, Andri. Masa Depan Pasar Modal Syariah Di Indonesia. Jakarta: Prenadamedia Group, 2014.

Ticmi. Pengetahuan Tentang Efek Yang Diperdagangkan Di Pasar Modal. Jakarta Selatan: Ticmi, 2016. 